ABDIMAS: Jurnal Pengabdian Masyarakat Universitas Merdeka Malang
Vol.6(4) November 2021, 588-599
p-ISSN: 2721-138X e-ISSN: 2548-7159
http://jurnal.unmer.ac.id/index.php/jpkm

\title{
Financial management and product marketing training for the Program Keluarga Harapan Groups
}

\section{Pelatihan pengelolaan keuangan dan pemasaran produk bagi Kelompok Program Keluarga Harapan}

\author{
Wulan Dri Puspita', Dewi Ayu Rahayu² \\ ${ }^{1}$ Departemen D3 Akuntansi, Fakultas Ekonomi dan Bisnis, ²Departemen Hukum, Fakultas Hukum, \\ Universitas Merdeka Malang \\ Jl. Terusan Raya Dieng No.62-64 Malang, 65146, Indonesia
}

ARTICLE INFO
Received: 2021-03-26
Revised: 2021-05-02
Accepted: 2021-08-19
Keywords:
Google form, Inventory
and marketing,
Marketplace, The
Program Keluarga
Harapan

\section{ABSTRACT}

The managing of Hope Family Program or Program Keluarga Harapan (PKH) is the supervisor of the business unit in the form of electronic warung gotong royong (e-Warong) which is a social assistance program to synergies between PKH and the Joint Venture Group or Kelompok Usaha Bersama (KUBE). PKH of Bantur's subdistrict experienced several problems related to financial management for their business activities, especially their inventory recording and they were not aware to promote through marketplaces. Therefore by the program of community service the University of Merdeka Malang, PKH Bantur's subdistrict was expected to be able to gain an understanding of inventory recording and marketing to solve their problems by using google forms, google spreadsheet, and Shopee. There are three methods for these activities: lectures, practices, and discussions. These activities are divided into two sessions. The first session was introducing the importance of financial management, inventory management, and the use of google form and google spreadsheet. The second session explained digital marketing and the use of Shopee. The participants looked enthusiastic during the event. Through these activities, participants can understand the importance of managing inventory, the benefits of google form and google spreadsheets to control their inventory, also they can use Shopee as marketing media to gain more income.

(C)2021 Published by University of Merdeka Malang. This is an open access article distributed under the CC BY-SA 4.0 license (https://creativecommons.org/licenses/by-sa/4.0/)

How to cite: Puspita, W. D., \& Rahayu, D. A. (2021). Financial management and product marketing training for the Program Keluarga Harapan Groups. Abdimas: Jurnal Pengabdian Masyarakat Universitas Merdeka Malang, 6(4), 588-599. https://doi.org/10.26905/abdimas.v6i4.5626

\section{PENDAHULUAN}

Perwujudan kesejahteraan sosial bagi seluruh masyarakat Indonesia merupakan bagian dari butirbutir Pancasila dan pokok pikiran dalam pembukaan Undang-Undang Dasar Negara Republik Indonesia tahun 1945. Upaya untuk mewujudkan kesejahteraan bagi masyarakat tersebut telah dilakukan dengan membentuk Program Keluarga Harapan (PKH), yaitu program bantuan sosial bersyarat yang diberikan 
kepada keluarga miskin yang telah ditetapkan sebagai keluarga penerima manfaat (KPM). Program Keluarga Harapan mulai dilaksanakan sejak tahun 2007, dengan target sasaran adalah rumah tangga/ keluarga sangat miskin atau kelompok masyarakat pada klaster 1. PKH memiliki misi untuk menurunkan kemiskinan, menurunkan kesenjangan dan meningkatkan pembangunan manusia di Indonesia. Tujuan PKH menurut Peraturan Menteri Sosial No. 1 Tahun 2018 adalah meningkatkan taraf hidup masyarakat melalui pendidikan, kesehatan dan kesejahteraan masyarakat, mengurangi beban dan meningkatkan pendapatan rumah tangga, menciptakan kemandirian, mengurangi kemiskinan, dan mengenalkan manfaat produk serta jasa keuangan.

PKH tersebut dapat terlaksana karena adanya pelaksana/pendamping sosial PKH yang ditunjuk oleh Kementrian Sosial yang bertempat di beberapa wilayah yang ada di Indonesia. Pelaksana Program Keluarga Harapan menurut Syahabbudin merupakan perpanjangan tangan pemerintah dengan mandat untuk memerangi kemiskinan yang ada di Indonesia, dengan bekal ilmu pengetahuan mereka bertugas membuka pemikiran dan pengetahuan KPM sebagai bentuk peningkatan taraf hidup (Kementerian Sosial Republik Indonesia, 2021).

Pelaksana PKH Kecamatan Bantur ditunjuk oleh Kementrian Sosial sebagai perwakilan di Kecamatan Banturyang terbagi menjadi 10 bagian keluharan/desa, yaitu Bandungrejo, Bantur, Karangsari, Pringgondani, Rejosari, Sumberbening, Srigonco, Wonokerto, dan Wonorejo. Saat ini pelaksana PKH Kecamatan Bantur berkantor di Jalan Raya Bantur No. 1460, Kecamatan Bantur, Kabupaten Malang di bawah pengawasan Dinas Sosial Kabupaten Malang. Pelaksana PKH Kecamatan Bantur terdiri dari 10 orang dengan tingkat pendidikan Program D3 sebanyak 1 orang, Program S1 sebanyak 8 orang, dan Program S2 sebanyak 1 orang.

Pelaksana PKH juga merupakan pengawas atas unit usaha berupa elektronik warung gotong royong (e-Warong) yang merupakan program bantuan sosial dari sinergi antara PKH dengan Kelompok Usaha Bersama (KUBE). Anggota kelompok usaha tersebut merupakan KPM yang dipilih oleh pelaksana PKH. Pelaksana PKH memilih anggota KUBE dengan latar belakang tingkat pendidikan maksimal Sekolah Menengah Pertama (SMP). E-Warong merupakan media yang digunakan untuk meningkatkan taraf hidup KPM, kemandirian, dan pengenalan produk jasa keuangan melalui pembayaran elektronik. Melalui e-Warong mereka melakukan pembelian bahan pangan bersubsidi, penyaluran program subsidi, dan kegiatan usaha.

E-warong menyediakan kebutuhan sehari-hari seperti beras, telur, mie instan, sabun, detergen, dan lain-lain. Selama melakukan kegiatan usaha di e-Warong, mereka mengalami beberapa permasalahan, antara lain kesulitan dalam pencatatan persediaan, lemahnya pengendalian internal atas persediaan, dan kurangnya pemahaman mengenai pembuatan laporan keuangan. Akibatnya ketika ada persediaan yang hilang atau kelalaian atas pencatatan, maka tidak ada pengambilan keputusan yang diambil untuk mengakui persediaan tersebut termasuk tidak mencatatnya sebagai suatu kerugian.

Pencatatan persediaan selama ini dilakukan secara sederhana, yaitu hanya mencatat jumlah barang keluar ketika terjadi transaksi penjualan. Sementara untuk barang masuk tidak dilakukan pencatatan secara keseluruhan, hanya persediaan tertentu yang berhubungan langsung dengan pembagian bantuan sosial. Dasar dilakukannya pembelian adalah sisa jumlah barang yang ada di e-Warong. 
ABDIMAS: Jurnal Pengabdian Masyarakat Universitas Merdeka Malang Volume 6, No. 4, November 2021: 588-599

Kesulitan akan terjadi ketika pelaksana PKH maupun anggota KUBE tidak dapat mengetahui secara pasti apakah persediaan yang tersisa adalah benar-benar karena kegiatan penjualan. Selain itu, mereka juga tidak dapat mengetahui berapa keuntungan yang dihasilkan dari kegiatan bisnis tersebut. Belum adanya pemahaman mengenai pengendalian internal untuk melindungi fisik persediaan maupun melakukan stock opname yaitu menghitung antara pencatatan yang ada di buku Rudianto (2012) menjadi suatu fenomena yang menjadi perhatian pengawas e-Warong. Ketika pelaksana PKH mencoba melakukan penghitungan dengan membandingkan sisa persediaan periode sebelumnya ditambah barang yang dibeli dikurangi dengan penjualan, sering kali ditemukan perbedaan dengan jumlah persediaan fisik. Setelah dilakukan pengecekkan adakalanya ditemukan kelalaian dalam pencatatan persediaan yang keluar dan adakalanya tidak diketahui alasan perbedaan tersebut sehingga dicatat sebagai barang hilang tanpa adanya pengakuan atas kerugian.

Pengendalian internal, salah satunya fisik persediaan, dapat meminimalisir kerugian akibat kebocoran dalam kegiatan operasional (Puspita, 2012). Pengendalian atas persediaan dapat dilakukan dengan cara memperbaiki sistem pencatatan atas barang yang masuk dan keluar. Selain itu, adanya teknologi dapat dimanfaatkan untuk mempermudah akses dan membantu kegiatan operasional. Setelah itu penghitungan atas fisik persediaan secara berkala juga dapat dilakukan sehingga nantinya dapat dilakukan verifikasi antara catatan yang ada dengan sisa persediaan.

Pelaksana PKH memiliki program meningkatkan taraf hidup dan menciptakan kemandirian bagi KPM, program tersebut dapat ditunjang dengan kegiatan pengenalan mengenai aplikasi pemasaran seperti marketplace. Fenomena penggunaan internet yang semakin meningkat dan pengaruh internet untuk memperoleh hak akses atas informasi dapat membantu KPM dalam mengembangkan diri dengan kemajuan teknologi yang ada. Pelaksana PKH di Kecamatan Bantur menyadari adanya keterbatasan informasi yang diperoleh oleh KPM mengenai marketplace, tetapi di sisi lain beberapa KPM memiliki ketertarikan untuk mengetahui bagaimana penggunaan dan cara kerja marketplace. Berdasarkan informasi yang diperoleh dari salah satu pelaksana PKH, saat berada di e-Warong tidak jarang dari mereka bercengkrama mengenai penggunaan marketplace yang mempermudah masyarakat untuk memperoleh barang dari penjuru negeri dengan harga yang bersaing. Rasa ketertarikan tersebut juga menjadi salah satu alasan mengapa kegiatan pengenalan aplikasi marketplace ini dilakukan, selain dapat merasakan praktik secara langsung mereka juga dapat memperoleh informasi baru mengenai manfaat pemasaran menggunakan marketplace.

Saputra \& Ardani (2020) mengungkapkan bahwa penggunaan pemasaran melalui media digital dapat membantu meningkatkan penjualan bagi usaha mikro kecil dan menengah (UMKM) mulai dari $30 \%$ hingga $100 \%$. Hal tersebut karena jangkauan penjual terhadap konsumen semakin luas. Selain itu, mereka juga memiliki kemudahaan dalam melakukan transaksi tanpa harus bertatap muka langsung. Penggunaan marketplace juga dapat memperpendek rantai distribusi pemasaran karena konsumen dapat membeli langsung dari penjual, sehingga harga yang diperoleh pun menjadi lebih murah. Selain itu, proses pengawasan juga akan dilakukan oleh pihak marketplace untuk memverifikasi data pembelian maupun penjualan untuk melindungi kedua pihak tersebut. (Apriadi \& Saputra, 2017).

Perkembangan teknologi informasi dapat digunakan untuk memecahkan permasalahan yang nantinya digunakan untuk pengambilan keputusan salah satunya menggunakan teknologi digital dan 
internet. Salah satu solusi yang dapat digunakan untuk memecahkan masalah pecatatan persediaan adalah dengan menggunakan aplikasi Google Drive berupa Google Form dan Google Spreadsheet. Google Form merupakan aplikasi pembuatan formulir online yang digunakan untuk mengumpulkan respon, sementara Google Spreasheet adalah aplikasi spreadsheet online yang dapat digunakan untuk menambahkan, mengedit, atau mengformat teks, serta angka hingga formula.

Novita \& Wulanditya (2020) pernah membuat desain pencatatan akuntansi menggunakan Microsoft Excel untuk usaha mikro kecil menengah (UMKM), hasilnya dengan menggunakan format perhitungan yang ada pada Microsoft Excel dapat membantu UMKM tersebut dalam pencatatan laporan keuangan. Google Spreadsheet memiliki beberapa fitur yang mirip dengan Microsoft Excel dengan basis cloud computing yaitu aksesnya menggunakan internet. Pemanfaatan Google Spreadsheet untuk membuat laporan keuangan pernah dilakukan oleh Muhammad et al. (2020) pada UMKM di Kota Bandung. Kegiatan tersebut telah berhasil meningkatkan kesadaran pelaku UMKM akan pentingnya laporan keuangan dan meningkatkan kemampuan penggunaan Google Spreadsheet untuk laporan keuangan. Penggunaan Google Spreadsheet memiliki keunggulan karena biayanya yang gratis, dapat diakses secara bersama-sama dan dimana saja, sehingga proses akuntansi dapat dilakukan secara cepat, akurat dan transparan (Lovita, 2020).

Pelaksanaan pemasaran dapat dilakukan dengan menggunakan media e-commerce. E-commerce merupakan suatu proses membeli dan menjual produk-produk secara elektronik oleh konsumen maupun dari entitas bisnis satu ke entitas bisnis lainnya dengan menggunakan komputer sebagai perantara transaksi bisnis (Arfan et al., 2018). Penjualan produk menggunakan e-commerce dapat menciptakan peluang bisnis baru tanpa harus memiliki produk maupun toko terlebih dahulu (Khasanah et al., 2020). Evasari et al. (2019) melakukan pengabdian masyarakat dengan menerapkan e-commerce pada UMKM di Desa Tales. Hasil kegiatan tersebut mampu meningkatkan motivasi bagi pelaku UMKM untuk menaikkan penjualannya melalui pemasaran. Salah satu e-commerce yang sering digunakan oleh masyarakat adalah Shopee, yaitu platform jual beli online berbasis mobile application. Shopee merupakan e-commerce yang paling banyak diminati oleh masyarakat karena informasinya menarik dan fitur aplikasi yang mempermudah pemakaian setiap individu (Viona et al., 2021).

Program pengabdian masyarakat ini dilakukan untuk membantu PKH Kecamatan Bantur dalam mengatasi permasalahan yang dihadapi. Pemberian pelatihan dalam pengelolaan keuangan menggunakan Google Form dan Google Spreadsheet diharapkan dapat membantu mereka mengelola persediaan agar lebih tertata. Adanya aplikasi tersebut nantinya PKH Kecamatan Bantur dapat mengetahui berapa jumlah persediaan yang dibeli dan berapa jumlah persediaan yang terjual untuk masing-masing jenis persediaannya. Selain itu, mereka juga dapat melihat laba kotor atas kegiatan usaha yang dilakukan. Salah satu wadah e-commerce adalah aplikasi marketplace yaitu Shopee. Sementara penggunaan aplikasi Shopee dapat digunakan sebagai alternatif dalam membantu memasarkan produk, sehingga dapat membantu meningkatkan penjualan. Shopee dipilih karena aplikasi tersebut menempati peringkat pertama di kuartal keempat tahun 2019 sebagai aplikasi yang banyak diakses oleh masyarakat Indonesia (Ikhsan, 2020). 
ABDIMAS: Jurnal Pengabdian Masyarakat Universitas Merdeka Malang

Volume 6, No. 4, November 2021: 588-599

\section{METODE}

Koordinasi dengan perwakilan pelaksana PKH yang ada di Kecamatan Bantur dilakukan terlebih dahulu dengan mengatur jadwal dan tempat kegiatan. Koordinasi awalnya dijadwalkan pada awal April, tetapi karena ada larangan untuk berkumpul dalam satu ruangan untuk mencegah menularnya COVID-19 maka kegiatan diundur hingga kondisi memungkinkan. Koordinasi kembali dilakukan pada Oktober dengan kesepakatan bahwa kegiatan pengabdian kepada masyarakat akan dilakukan pada 24 November 2020. Selanjutnya melalui perwakilan pelaksana PKH proses memberian undangan akan dilakukan kepada 20 calon peserta.

Kegiatan dilaksanakan di Jalan Raya Wonokerto No. 13 Rt. 03 Rw. 01 Kabupaten Malang mulai pukul 08.00-15.00 WIB. Dari 20 calon peserta terdapat 15 peserta yang telah mengikuti kegiatan. Peserta terdiri dari 4 pelaksana PKH dan 11 anggota KUBE. Pelaksanaan kegiatan dilakukan menggunakan tiga metode yaitu; ceramah, praktik dan diskusi.

\section{Ceramah}

Ceramah diberikan untuk meningkatkan pemahaman mengenai pentingnya materi yang akan diberikan meliputi laporan keuangan dan fungsi persediaan. Pemberian materi mengenai penggunaan Google Form dan Google Spreadsheet juga akan diberikan karena digunakan untuk mengelola persediaan. Untuk meningkatkan pemasaran fungsi aplikasi Shopee juga dipaparkan untuk membantu meningkatkan penjualan.

\section{Praktik}

Praktik bertujuan untuk mengasah keterampilan dalam pengelolaan persediaan dan promosi. Pengelolaan persediaan dilakukan dengan praktik langsung mengisi Google Form. Data-data yang diisi pada Google Form akan terekam di Google Spreadsheet, selanjutnya data tersebut akan diolah menggunakan pivot. Pivot merupakan suatu fitur untuk mengolah data dengan meringkas sekumpulan data dari sudut pandang yang dikehendaki (Kusrianto, 2007). Selain menggunakan Microsoft Excel, fungsi pivot juga dapat ditemui pada Google Spreasheet. Penggunaan pivot dapat mengidentifikasi jumlah masing-masing persediaan yang dibeli dan dijual. Selain itu, juga dapat menghitung sisa persediaan yang ada.

Praktik media promosi menggunakan aplikasi e-commere dipilih karena saat ini masyarakat cenderung melakukan belanja online yang dinilai aman. Aplikasi yang dipilih adalah Shopee yaitu e-commerce perikat pertama di Indonesia (Christy, 2020). Praktik promosi dilakukan dengan membuat akun shopee untuk penjual, memverifikasi data, memposting produk yang akan dijual, hingga penggunaan promosi toko yang disiapkan oleh Shopee.

\section{Diskusi}

Diskusi dilakukan untuk menggali secara lebih mendalam mengenai permasalahan yang dihadapi. Metode ini akan membantu mereka untuk memberikan alternatif-alternatif pemecahan masalah yang 
dapat mereka gunakan selama melakukan kegiatan bisnis. Pelaksanaan kegiatan pengabdian masyarakat ini dilakukan selama satu hari dengan dibagi ke dalam dua sesi.

Tabel 1. Jadwal pelaksanaan kegiatan pengabdian masyarakat

\begin{tabular}{|c|c|}
\hline \multicolumn{2}{|c|}{ Sesi Pertama } \\
\hline Aktivitas & $\begin{array}{l}\text { - Penjelasan mengenai laporan keuangan } \\
\text { - Penjelasan mengenai pengelolaan persediaan } \\
\text { - Pengenalan aplikasi Google Form dan Google Spreadsheet }\end{array}$ \\
\hline Tujuan & $\begin{array}{l}\text { - Memperoleh pemahaman mengenai pentingnya laporan keuangan } \\
\text { - Memperoleh pemahaman mengenai pentingnya mengelola persediaan } \\
\text { pembelian persediaan }\end{array}$ \\
\hline \multicolumn{2}{|c|}{ Sesi Kedua } \\
\hline Aktivitas & $\begin{array}{l}\text { - Penjelasan mengenai pemasaran digital } \\
\text { - Pengenalan aplikasi Shopee }\end{array}$ \\
\hline Tujuan & $\begin{array}{l}\text { - Memperoleh pemahaman mengenai pentingnya pemasaran digital } \\
\text { - Praktik pembuatan akun Shopee beserta fitur-fitur di dalamnya }\end{array}$ \\
\hline
\end{tabular}

\section{HASIL DAN PEMBAHASAN}

\section{Hasil}

Kunjungan ke rumah perwakilan PKH Kecamantan Bantur telah dilakukan pada tanggal 2 Oktober 2020. Kunjungan tersebut dalam rangka koordinasi pendahuluan yang bertujuan untuk membahas langkah selanjutnya dalam pelaksanaan kegiatan pengabdian kepada masyarakat. Koordinasi tersebut menghasilkan kesepakatan bahwa kegiatan pengabdian masyarakat akan dilaksanakan pada 24 November 2020.

Kegiatan pengabdian masyarakat dilaksanakan di Desa Wonokerto Kecamatan Bantur Kabupaten Malang. Peserta kegiatan merupakan mereka pengguna Android, pernah melakukan transaksi menggunakan sosial media seperti WhatsApp maupun Facebook serta pernah mendengar mengenai Google dan Shopee. Pelaksana PKH diwakili oleh 3 orang, berpendidikan D3 dan S1 yang bertugas mendampingi KPM melalui kegiatan berupa kesehatan, pendidikan, dan kesejahteraan sosial, serta menjadi pengawas e-Warong. Sementara KPM terdiri dari 12 orang dengan latar belakang pendidikan SMP. Background pekerjaan mereka sebagai buruh dan ibu rumah tangga yang tergabung menjadi pengelola e-Warong, serta KPM pemilik usaha mikro yang berkeinginan untuk mengembangkan usahanya. Pengamatan awal memperlihatkan bahwa peserta belum memahami mengenai pengelolaan persediaan, belum mengenal aplikasi Google Form dan Google Spreadsheet tetapi pernah mendengar mengenai Google dan aplikasi marketplace terutama Shopee walaupun belum semuanya paham mengenai cara penggunaannya.

Pelaksanaan kegiatan dibagi menjadi tiga tahap, yaitu presentasi, praktik, dan diskusi. Kegiatan pertama dari pengabdian masyarakat ini adalah menjelaskan mengenai pentingnya laporan keuangan. Laporan keuangan sangat berguna sebagai alat pertanggungjawaban penggunaan dana dan kegiatan operasional perusahaan serta dapat mengetahui laba bersih yang diterima oleh suatu entitas. Laporan inilah yang menjadi pedoman untuk mengambil beberapa keputusan atau pun kebijakan-kebijakan di masa datang. Untuk membantu membuat laporan keuangan, entitas harus dapat mengelola persediaan terlebih dahulu. 
ABDIMAS: Jurnal Pengabdian Masyarakat Universitas Merdeka Malang Volume 6, No. 4, November 2021: 588-599

Kenyataannya, selama ini pengelolaan persediaan masih dilakukan berdasarkan jumlah barang yang dibeli dan dijual tanpa adanya pengendalian terhadap bentuk fisik barang. Jika barang habis di toko maka pembelian baru akan dilakukan tanpa diketahui apakah barang tersebut benar terjual, rusak, ataupun hilang. Ada dua metode persediaan yaitu periodik yang pencatatannya dilakukan per periode dan pencatatan perpektual yang dilakukan setiap kali terjadi perubahan persediaan (Weygandt et al., 2018). Pada kegiatan pelatihan ini, persediaan dilakukan mengacu pada metode perpektual karena jumlah barangnya yang bermacam-macam.
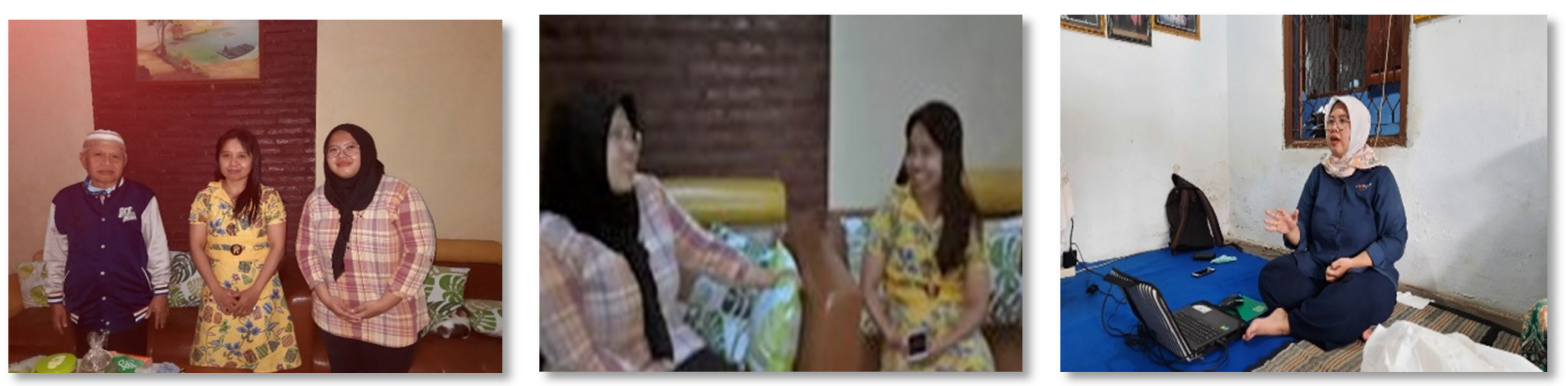

Gambar 1. Koordinasi dengan perwakilan PKH

Gambar 2. Penjelasan materi persediaan

Kegiatan kedua adalah praktik penggunaan aplikasi. Aplikasi pertama yang dipraktikan adalah Google Form dan Google Spreadsheet untuk mengelola persediaan. Google Form digunakan untuk membuat formulir yang berhubungan dengan transaksi persediaan, yaitu penjualan dan pembelian. Formulir tersebut terbagi dalam beberapa pertanyaan yaitu; jenis kegiatan, nama barang, harga barang, dan jumlah barang.

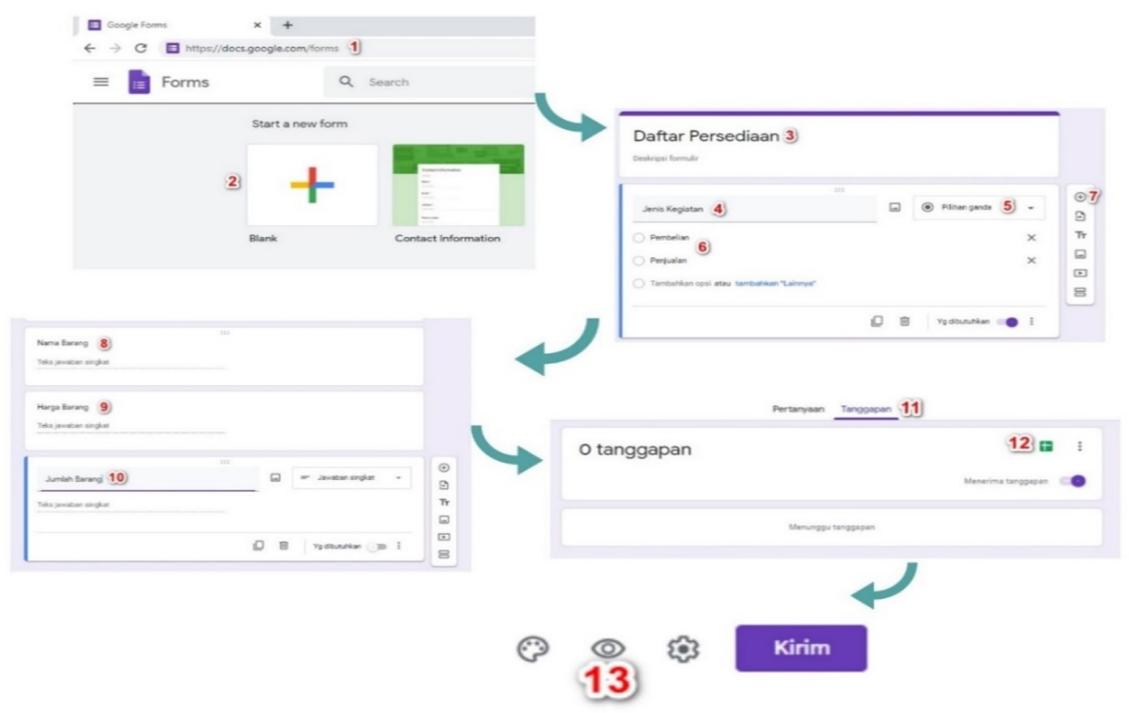

Gambar 3. Pembuatan daftar persediaan 
Setelah formulir dibuat, fitur Google Spreadsheet akan diaktifkan sehingga semua data yang masuk nantinya akan otomatis masuk kesana. Peserta kemudian melakukan simulasi dengan memasukkan transaksi berdasarkan jenis kegiatannya, yaitu pembelian atau penjualan. Kemudian perserta memasukkan nama barang, harga barang dan jumlah barang. Data transaksi yang dimasukkan akan tersimpan pada Google Spreadsheet. Fitur Google Spreadsheet akan memperlihatkan waktu pengisian Google Form, jenis kegiatan yang dipilih, detail nama barang, jumlah barang, dan harga barang yang dijual atau dibeli.

Penggunaan fungsi pivot juga digunakan untuk membaca informasi mengenai ringkasan data jika data yang dimasukkan dalam jumlah banyak. Tujuan penggunaan fungsi pivot untuk melihat berapa sisa persediaan yang tercatat. Penggolongan dilakukan berdasarkan nama barang dan jenis kegiatan. Selanjutnya, setiap barang akan menampilkan informasi mengenai berapa jumlah barang pada kegiatan pembelian dan penjualan. Untuk mencari sisa persediaan dilakukan fungsi penggurangan secara manual antara jumlah barang yang dibeli dengan jumlah barang yang dijual.
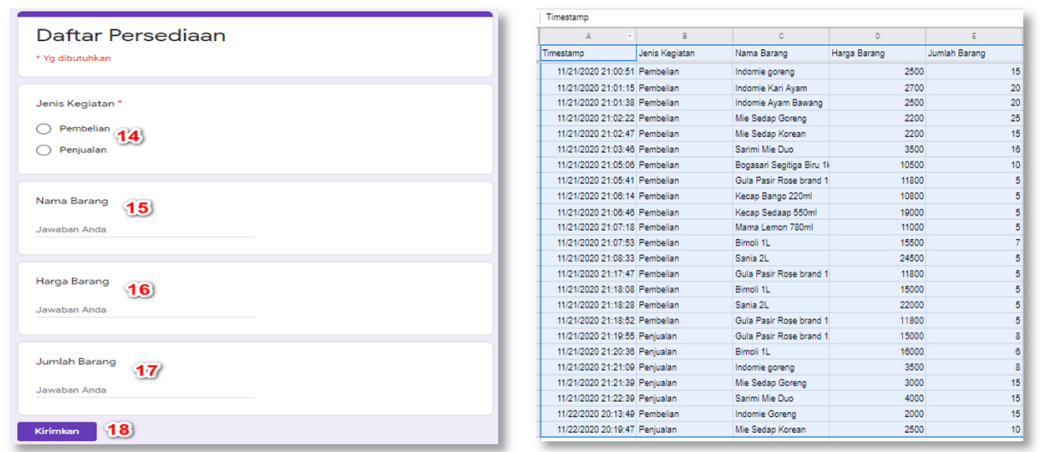

Gambar 4. Gambar form persediaan

Gambar 5. Tampilan daftar persediaan

Gambar 6. Tampilan perhitungan sisa persediaan

Aplikasi kedua yang dipraktikkan adalah Shopee. Shopee merupakan e-commerce yang paling mudah dijalankan oleh pengguna dalam melakukan jual beli secara elektroknik. Shopee menawarkan fitur toko online sehingga setiap individu dapat dengan mudah membuka toko melalui aplikasi yang ada di handphone atau komputer. Setiap peserta melakukan registrasi baik melalui aplikasi yang ada di mobile seluler atau laman resmi shopee.co.id untuk membuat akun baru. Diperlukan verifikasi atas akun tersebut baru pengaturan atas toko dapat dilakukan.

Setelah toko selesai diatur, masing-masing peserta mencoba memasukkan produk yang akan dipasarkan di Shopee. Selain fitur toko, Shopee juga memiliki fitur Live Chat untuk mempermudah pembeli berkomunikasi dengan dengan penjualan. Penjual juga dapat melihat berapa pendapatan atas penjualan yang mereka peroleh melalui fitur keuangan. 
ABDIMAS: Jurnal Pengabdian Masyarakat Universitas Merdeka Malang Volume 6, No. 4, November 2021: 588-599
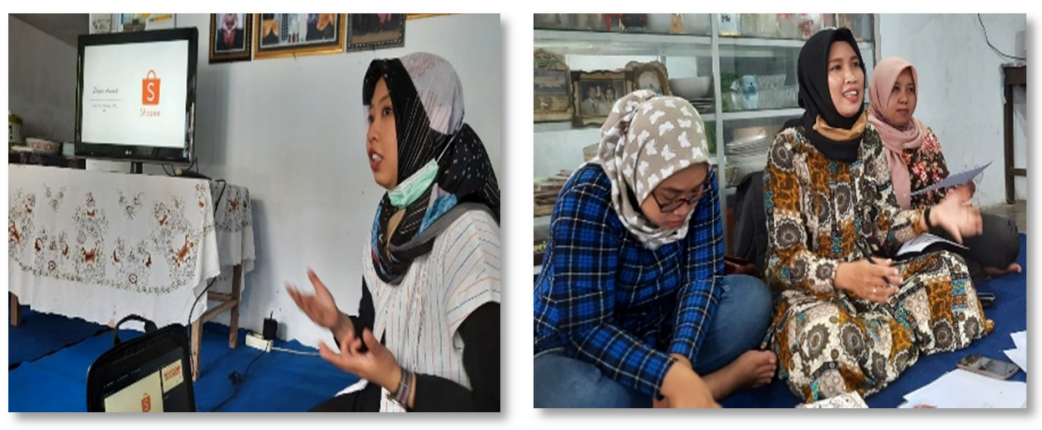

Gambar 7. Penjelasan mengenai aplikasi Shopee Gambar 8. Antusias peserta saat sesi diskusi

Kegiatan terakhir adalah diskusi. Peserta sangat antusias selama kegiatan pelaksanaan, hal tersebut dapat dilihat dari pertanyaan-pertanyaan yang diberikan selama sesi diskusi. Pertanyaan-pertanyaan yang dilontarkan seputar pengendalian persediaan, seperti pencarian persediaan yang hilang akibat kelalaian pencatatan, kesulitan dalam verifikasi akun Shopee hingga penggunaan fitur pengaturan produk.

Melalui kegiatan ini paling tidak dapat membantu peserta mengenai pentingnya perekonomian keluarga. Harapan selanjutnya, dengan adanya kegiatan ini para peserta dapat terjun langsung untuk memulai usaha sehingga mereka dapat memperoleh pendapatan tambahan bahkan menjadi usaha utama untuk kesejahteraan keluarga.

\section{Pembahasan}

Kegiatan pengabdian masyarakat melalui pelatihan pengelolaan keuangan dan pemasaran menggunakan aplikasi digital memiliki relevansi karena saat ini aktivitas masyarakat tidak terlepas dari digitalisasi. Kegiatan ini bertujuan untuk menambah pengetahuan peserta mengenai laporan keuangan, pengelolaan persediaan, dan pemasaran. Hal tersebut ditunjang dengan adanya komunikasi dengan pihak mitra, yaitu pelaksana PKH Kecamatan Bantur. Target peserta merupakan pelaksana PKH dan anggota KUBE yang berkecimpung dalam kegiatan usaha terutama pada usaha e-Warong.

Berdasarkan hasil wawancara tidak terstruktur dan pengamatan antara tim pelaksana dengan peserta dapat diperoleh hasil sebagai berikut: (1) Kegiatan pengabdian masyarakat ini telah meningkatkan pengetahuan mereka mengenai pentingnya laporan keuangan dan pengelolaan persediaan, terutama untuk menjaga bentuk dan jumlah fisik persediaan yang ada di toko maupun gudang mereka; (2) Meningkatkan pengetahuan mereka mengenai kegunaan aplikasi Google Form dan Google Spreadsheet yang dapat digunakan untuk membantu pencatatan persediaan. Semua peserta telah melakukan kegiatan pengisian transaksi penjualan atau pembelian melalui link aplikasi Google Form, tetapi hanya 2 peserta yang berhasil membuat fitur Google Form; (3) Meningkatkan pengetahuan mereka mengenai pemanfaatan aplikasi Shopee sebagai media pemasaran produk untuk meningkatkan penjualan. Semua peserta telah melakukan upaya untuk mengunduh dan mendaftar pada aplikasi Shopee, tetapi hanya 7 peserta yang sudah dapat membuat, mengakses dan mengatur akun Shopee-nya. 

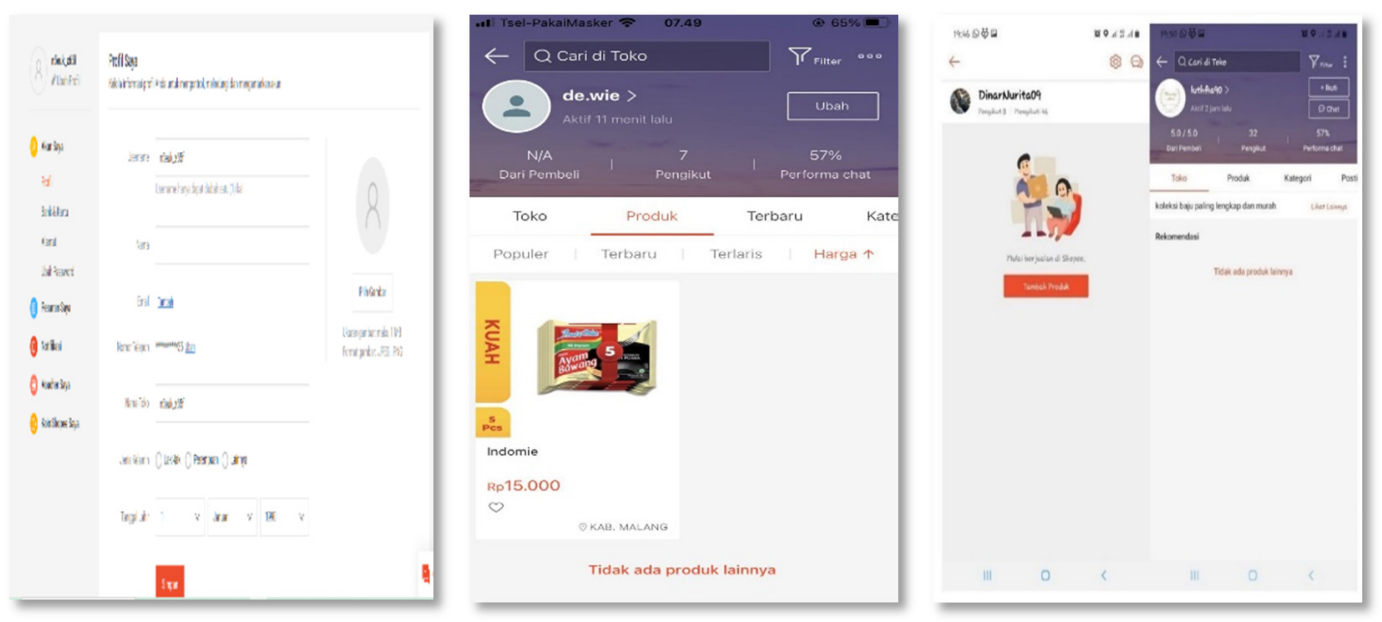

Gambar 9. Tampilan akun Shopee versi desktop

Gambar 10. Tampilan Toko versi mobile

Gambar 11. Tampilan toko Shopee yang berhasil dibuat oleh peserta

Pelaksanaan pengabdian masyarakat ini dapat terlaksanakan karena adanya dukungan dari berbagai pihak antara lain: (1) Adanya bantuan dari tokoh masyarakat desa Wonokerto dengan memberikan fasilitas berupa tempat pelaksanaan kegiataan dan keikutsertaan peserta yang merupakaan kelompok PKH yang bersedia terlibat dalam pelatihan ini; (2) Adanya minat dan antusiasme peserta selama kegiatan, hal tersebut dapat dilihat dari jumlah peserta yang tidak mengalami pengurangan selama acara berlangsung; (3) Antusias peserta juga dapat dilihat melalui keaktifan saat sesi diskusi maupun ketika mereka mengalami kesulitan dalam menjalankan aplikasi.
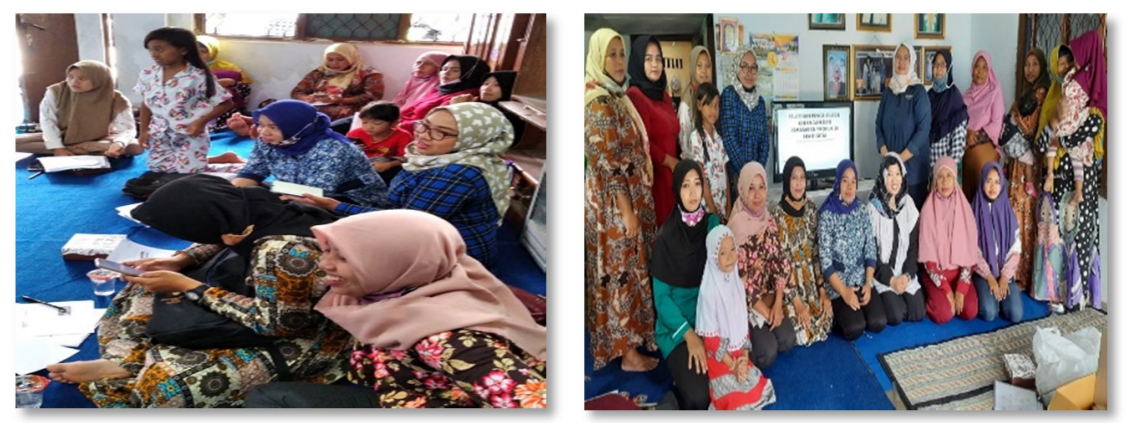

Gambar 12. Antusias peserta saat mendengarkan pemateri

Gambar 13. Penutupan kegiatan

Pengabdian masyarakat ini juga tidak lepas dari hambatan yang terjadi selama pelaksanaan kegiatannya, yaitu: (1) Perangkat mobile seluler milik peserta yang tidak dapat terkoneksi dengan jaringan maupun tidak dapat menggunduh aplikasi Shopee; (2) Peserta yang lupa akun email Googlenya untuk dapat membuat formulir maupun membuat akun di Shopee; (3) Kesulitan melakukan verifikasi dengan 
ABDIMAS: Jurnal Pengabdian Masyarakat Universitas Merdeka Malang

Volume 6, No. 4, November 2021: 588-599

mobile seluler, karena nomor yang didaftarkan tidak sama dengan nomor yang terpasang; (4) Karena pelatihan ini menitikberatkan pada praktik, terkadang beberapa peserta masih sulit untuk mengejar peserta lainnya mengenai tahap-tahap yang harus dilakukan dalam pengoperasian aplikasi.

\section{SIMPULAN DAN SARAN}

Kegiatan yang dilakukan mendapat respon positif, hal tersebut terlihat dari antusias peserta melalui pertanyaan-pertanyaan yang diberikan kepada pemateri. Selain itu, kegiatan seperti ini juga dapat menjadi wadah pengetahuan baru bagi kelompok PKH untuk selanjutnya dapat diterapkan secara langsung pada e-Warong. Penggunaan bantuan aplikasi diharapkan dapat mempermudah pekerjaan dan meningkatkan kesejahteraan. Implementasi aplikasi e-commerce layak untuk diterapkan sebagai media promosi usaha, salah satunya menggunakan aplikasi Shopee. Aplikasi tersebut dapat membantu perniagaan sehingga meningkatkan penjualan maupun belajar berwirausaha. Sementara pencatatan persediaan menggunakan bantuan Google Form dan Google Spreadsheet cocok digunakan apabila pengusaha memiliki persediaan yang beraneka ragam dan membutuhkan pengendalian internal. Selain itu, penggunaan pivot dapat membantu wirausaha melihat pendapatan dan belanja yang dilakukan oleh usahanya.

Kegiatan ini memiliki keterbatasan waktu dan pendanaan, sedangkan dari pelatihan tersebut masih terdapat peserta pelatihan yang belum bisa membuat akun Shopee maupun menggunakan fitur google, bahkan untuk mengaksesnya masih perlu untuk didampingi. Di sisi lain, baik Shopee maupun fitur google merupakan wadah yang mudah untuk mengembangkan usaha. Untuk itu diperlukan pendampingan dan pendanaan demi meningkatkan kemampuan masyarakat dalam menggunakan media digital sebagai upaya mengembangkan usaha dan promosi. Pendampingan dapat dilakukan secara individu atau kelompok kecil kepada pelaku usaha sehingga informasi yang diberikan dapat terserap lebih maksimal. Selain itu, tempat kegiatan harus dipastikan memiliki koneksi internet yang stabil serta menyediakan media verifikasi 2 langkah baik melalui email maupun nomor perangkat seluler.

\section{DAFTAR PUSTAKA}

Apriadi, D., \& Saputra, A. Y. (2017). E-Commerce berbasis marketplace dalam upaya mempersingkat distribusi penjualan hasil pertanian. Jurnal RESTI (Rekayasa Sistem dan Teknologi Informasi), 1(2), 131-136. https://doi.org/10.29207/resti.v1i2.36

Arfan, M., Hidayatno, A., \& Ramadhani, N. P. (2018). Optimalisasi entitas ecommerce dengan menggunakan cloud marketplace. Transient: Jurnal Ilmiah Teknik Elektro, 7(1), 209-213. https://doi.org/10.14710/transient.7.1.209-213

Christy, F. E. (2020, 31 Agustus). Top 10 e-commerce di Indonesia Kuartal I 2020. Tempo.co. https:// data.tempo.co/data/907/top-10-e-commerce-di-indonesia-kuartal-i-2020, 21 Desember 2020

Evasari, A. D., Utomo, Y. B., \& Ambarwati, D. (2019). Pelatihan dan pemanfaatan e-commerce sebagai media pemasaran produk UMKM di Desa Tales Kecamatan Ngadiluwih Kabupaten Kediri. Cendekia: Jurnal Pengabdian Masyarakat, 1(2), 75. https://doi.org/10.32503/cendekia.v1i2.603 


\section{Financial management and product marketing training for the Program Keluarga Harapan Groups Wulan Dri Puspita, Dewi Ayu Rahayu}

Humas BBPPKS Yogyakarta. (2020). Pendamping PKH, perpanjangan tangan pemerintah entaskan kemiskinan. https://kemensos.go.id/pendamping-pkh-perpanjangan-tangan-pemerintahentaskan-kemiskinan, 27 September 2021

Ikhsan, M. (2020, November 20). Kompetisi e-commerce di Asia Tenggara: Perusahaan lokal juara. CNN Indonesia. https://www.cnnindonesia.com/teknologi/20201020200745-206-560723/ kompetisi-e-commerce-di-asia-tenggara-perusahaan-lokal-juara

Kementerian Sosial Republik Indonesia. (2021). Program Keluarga Harapan (PKH). https://kemensos.go.id/program-keluarga-harapan-pkh

Kusrianto, A. (2007). PivotTable Excel untuk membuat laporan dan analisis data. Elex Media Komputindo, Jakarta

Lovita, E. (2013). Application of "Cloud Computing" in SMES simple accounting process for effective and efficient effort to penetrate global markets. Sustainable Competitive Advantage (SCA), 2(1).

Muhammad, R., Hendriyana., \& Ardimansyah, M. I. (2020). Penerapan Google Spreadsheet dalam pembuatan laporan keuangan untuk pengembangan usaha UMKM Kota Bandung. Ikra-Ith Abdimas, 3(1), 101-106.

Novita, S. M., \& Wulanditya, P. (2020). Desain microsoft excel for accounting bagi UMKM (studi kasus pada LS Farm Mojokerto). Jurnal Riset Terapan Akuntansi, 4(2), 192-205. https://doi.org/10.5281/zenodo.4275749

Peraturan Menteri Sosial Republik Indonesia Nomor 1 Tahun 2018 tentang Program Keluarga Harapan.

Puspita, W. D. (2012). Upaya penyempurnaan implementasi sistem penjualan dan penerimaan kas pada UD. Bagus Agriseta Mandiri. Jurnal Ilmiah Mahasiswa FEB, 1(1)

Rudianto. (2012). Pengantar akuntansi: konsep dan teknik penyusunan laporan keuangan. Jakarta: Erlangga.

Saputra, G. W., \& Ardani, I. G. A. K. S. (2020). Pengaruh digital marketing, word of mouth, dan kualitas pelayanan terhadap keputusan pembelian. E-Jurnal Manajemen Universitas Udayana, 9(7), 2596. https://doi.org/10.26533/jmd.v1i2.175

Khasanah, F. N., Herlawati, Samsiana, S., Handayanto, R. T., Gunarti, A. S. S., Raharja, I., ... Benrahman. (2020). Pemanfaatan media sosial dan ecommerce sebagai media pemasaran dalam mendukung peluang usaha mandiri pada masa pandemi COVID 19. Jurnal Sains Teknologi dalam Pemberdayaan Masyarakat, 1(1), 51-62. https://doi.org/10.31599/jstpm.v1i1.255

Viona, V., Yohanes, K., Kurniawati, L. S. M. W., Marta, R. F., \& Isnaini, M. (2021). Narasi Shopee dalam mengembangkan ekonomi kreatif berbasis teknologi e-commerce di era modern. Jurnal Ilmu Komunikasi, 1(2), 46-65.

Weygandt, J. J., Kimmel, P. D., \& Kieso, D. E. (2018). Pengantar Akuntansi 1. Jakarta: Salemba Empat. 